\title{
Effect of varying prepartum dietary cation-anion difference and calcium concentration on postpartum mineral and metabolite status and milk production of multiparous cows
}

\author{
A. L. Diehl, ${ }^{*}$ J. K. Bernard, ${ }^{* 1}$ S. Tao, ${ }^{*}$ T. N. Smith, ${ }^{*}$ D. J. Kirk, † D. J. McLean, $†$ and J. D. Chapman† \\ *Department of Animal and Dairy Science, University of Georgia, Tifton 31793 \\ †Phibro Animal Health Corp., Teaneck, NJ 07666
}

\begin{abstract}
Eighty-two multiparous Holstein cows were enrolled $28 \mathrm{~d}$ before expected calving and assigned to 1 of $4 \mathrm{di}-$ etary treatments in a randomized block design experiment with a $2 \times 2$ factorial arrangement of treatments to determine the effect of feeding a neutral or acidogenic diet varying in $\mathrm{Ca}$ concentration on prepartum and postpartum intake, blood mineral and metabolite concentrations, and postpartum milk production. Prepartum diets were formulated to provide a dietary cation-anion difference (DCAD) of -21 (negative, NEG) or -2 (neutral, NEU) $\mathrm{mEq} / 100 \mathrm{~g}$ of dry matter with either $1.3 \%$ or $1.8 \%$ Ca. After calving, cows remained on trial through $63 \mathrm{~d}$ in milk (DIM) and were fed a common lactation diet. Urine $\mathrm{pH}$ was lower for NEG compared with NEU and tended to be lower for $1.8 \%$ Ca compared with 1.3\% Ca. Fractional excretion of Ca and $\mathrm{Mg}$ in urine was greater for NEG than for NEU. Prepartum plasma bicarbonate was lower and $\mathrm{P}$ was higher for NEG compared with NEU. Prepartum plasma $\mathrm{P}$ and blood urea nitrogen to creatinine ratio was higher for $1.3 \%$ compared with $1.8 \%$ Ca. Postpartum, concentrations of plasma total protein, albumin, blood urea nitrogen, $\mathrm{Mg}$, and ionized $\mathrm{Mg}$ (iMg) were higher and Na was lower for NEU compared with NEG. An interaction of DCAD and Ca was observed for plasma creatinine, which was highest for cows fed NEU and 1.3\% Ca compared with all other treatments. Interactions of DCAD and DIM were observed for plasma bicarbonate and iMg. Bicarbonate was higher at 3 DIM and lower at 14 DIM for NEU compared with NEG. Concentrations of iMg were higher at 1, 2, and 14 DIM for NEU compared with NEG. Interactions of Ca and DIM were observed for plasma $\mathrm{Ca}, \mathrm{Cl}$, and anion gap. Compared with cows fed $1.5 \% \mathrm{Ca}$, those fed $1.3 \% \mathrm{Ca}$ had lower $\mathrm{Ca}$ and anion gap and higher $\mathrm{Cl}$ at 1 DIM and lower $\mathrm{Cl}$
\end{abstract}

Received March 26, 2018.

Accepted July 23, 2018.

${ }^{1}$ Corresponding author: jbernard@uga.edu and higher anion gap at 14 DIM. No differences were observed in body weight or body condition score due to DCAD or Ca. Prepartum dry matter intake (DMI) was lower for NEG compared with NEU and lower for 1.8\% compared with $1.3 \%$ Ca. Postpartum DMI was not different among treatments. An interaction was observed for DCAD and DIM due to higher milk yield after 45 DIM for NEG compared with NEU. No differences were observed in milk component percentage or yield among treatments. There was an interaction of DIM and Ca for milk urea concentrations, which were higher at 5 wk and lower at 6 wk for $1.3 \%$ Ca compared with $1.8 \%$ Ca. These results suggest that feeding NEG prepartum alters plasma and urine mineral concentrations compared with feeding NEU and supports increased milk yield after 45 DIM. Feeding $1.8 \%$ Ca prepartum only improved plasma Ca at 1 DIM. Feeding either NEG or $1.8 \% \mathrm{Ca}$ reduced DMI prepartum compared with NEU or $1.3 \% \mathrm{Ca}$.

Key words: dietary cation-anion difference, calcium, milk yield

\section{INTRODUCTION}

During the transition period, cows are at highest risk for metabolic diseases and health complications. Hypocalcemia often arises from the increased Ca demands paired with the delay in Ca absorption and bone mobilization after calving, resulting in low blood Ca concentrations. Cows with hypocalcemia have lower milk production and increased risk of other health disorders such as mastitis, displaced abomasum, and retained placenta (Curtis et al., 1985). Block (1984) and Oetzel (1991) determined that feeding anions to create a negative DCAD prepartum effectively altered Ca homeostasis to decrease the incidence of milk fever and improve production and health compared with positive DCAD.

Cows fed negative-DCAD diets prepartum have a Ca requirement of $1.0 \%$ to $1.5 \%$ (NRC, 2001). However, inclusion within the NRC recommendation to further alter Ca homeostasis has been debated by researchers 
and consultants given the higher milk yield of modern dairy cows. Mixed results have been reported on intake and blood Ca concentration due to dietary Ca concentrations. Some have observed that inclusion rates greater than $1.0 \%$ Ca decrease DMI (Miller, 1983), whereas others have fed up to $1.8 \%$ Ca with no effects on DMI (Beede and Shearer, 1991). Chan et al. (2006) reported no change in blood Ca concentration for diets containing $0.99 \%$ compared with $1.5 \% \mathrm{Ca}$ in diets with a DCAD of $-6 \mathrm{mEq} / 100 \mathrm{~g}$. Oba et al. (2011) demonstrated improved blood Ca concentration when feeding $0.9 \%$ compared with $0.3 \%$ Ca. These results suggest that $1.0 \% \mathrm{Ca}$ prepartum with a negative-DCAD diet may be sufficient for maintaining blood Ca during the immediate postpartum period. The objective of this trial was to determine the effect of feeding a neutral or acidogenic diet varying in $\mathrm{Ca}$ concentration during the close-up dry period on prepartum and postpartum DMI, blood mineral and metabolite status, and postpartum milk production.

\section{MATERIALS AND METHODS}

All methods were reviewed and approved by the University of Georgia Animal Care and Use Committee before conducting the trial. Ninety-two multiparous Holstein cows that had completed $1.9 \pm 1.0$ lactations (range: 1-4 lactation) were enrolled in a randomized block design experiment from January to October 2016. Cows were trained to eat behind Calan doors (American Calan, Northwood, NH) beginning $42 \pm 4$ d before expected parturition. Cows enrolled were fed experimental diets beginning at $28 \pm 4 \mathrm{~d}$ prepartum and were maintained on the trial through 63 DIM. Sample collection was initiated after $7 \mathrm{~d}$ to allow adaptation to the prepartum diets. Cows were blocked $(\mathrm{n}=23)$ by expected calving date and parity (second vs. third or greater) and assigned to 1 of 4 dietary treatments within block in the randomized block design experiment with a $2 \times 2$ factorial arrangement of treatments. Prepartum diets were formulated to provide a DCAD of -22 (negative, NEG) or -2 (neutral, NEU) $\mathrm{mEq} / 100 \mathrm{~g}$ of DM with $1.0 \%$ or $1.5 \%$ DM Ca. However, actual $\mathrm{Ca}$ concentrations were $1.3 \%$ and $1.8 \%$ due to high concentrations of $\mathrm{Ca}$ in the concentrate mix and brewers grains. Individual dietary treatments and the animals assigned to each were NEG-1.3\% Ca $(\mathrm{n}=20)$, NEG-1.8\% Ca $(\mathrm{n}=21)$, NEU-1.3\% Ca $(\mathrm{n}=20)$, and NEU-1.8\% Ca $(\mathrm{n}=21)$.

Cows were housed in a 4-row sand-bedded freestall barn equipped with fans and misters for evaporative cooling. Dry cows were housed separately from lactating cows and moved to the lactating pen after calving and retrained to a second Calan gate. Cows had access to a dry lot and water $24 \mathrm{~h} / \mathrm{d}$ and were fed once daily. Feed was manually pushed up twice daily. Experimental diets and a common lactating diet were formulated to meet or exceed NRC requirements (Table 1) and fed to provide a minimum of $5 \%$ refusal. Base ingredients were initially mixed to form a base mix. The base mix and remaining ingredients were mixed and individually fed using a DataRanger (American Calan). Amounts of feed offered and refused were recorded daily.

Samples of individual feed ingredients, experimental diets, and the common lactating diet were collected 3 times each week. Dry matter was determined using a forced-air drying oven set at $55^{\circ} \mathrm{C}$ for $48 \mathrm{~h}$. Samples were ground to pass through a $6-\mathrm{mm}$ screen and then a 2-mm screen using a Wiley mill (Thomas Scientific, Swedesboro, NJ) and composited by week. Samples were analyzed for protein (LECO FP-5258 Nitrogen Analyzer, St. Joseph, MO), ADF (AOAC International, 2000), NDF adjusted for ash (Van Soest et al., 1991), ether extract, and minerals (AOAC International, 2000). Body weight measurements were recorded on 3 consecutive days at $-21 \mathrm{~d}$ prepartum and 21,42 , and 63 DIM using digital scales. A BCS was assigned by one individual as described by Wildman et al. (1982) to maintain consistency throughout the trial. Immediately after calving, BW was measured and BCS was assigned once. The BW and BCS at $-21 \mathrm{~d}$ prepartum were used as the initial BW.

Blood samples were collected at $1300 \mathrm{~h}$ from the coccygeal vein or artery at $-21,-14,-7$, and $-2 \mathrm{~d}$ prepartum, immediately after calving (d 0$)$, and at 1 , 2, 3, 7, and 14 DIM. Three blood samples were collected in evacuated tubes and immediately placed in ice water. Two tubes did not contain anticoagulants, and the third tube contained sodium heparin. Immediately after collection, samples were transported to the University of Georgia Veterinary Diagnostic Lab (Tifton, GA) for analysis. Serum was separated and analyzed for total protein, albumin, globulin, urea N, creatinine, bilirubin, glucose, $\mathrm{Ca}, \mathrm{Mg}, \mathrm{Na}, \mathrm{K}, \mathrm{Cl}$, and bicarbonate using an Advia 1800 Chemistry System (Siemens Medical Solutions USA Inc., Malvern, PA). Anion gap was calculated from concentration of $\mathrm{Na}, \mathrm{K}, \mathrm{Cl}$, and bicarbonate. The sample collected with sodium heparin was immediately analyzed for ionized $\mathrm{Ca}$ (iCa) and ionized Mg (iMg; pHOx Ultra, Nova Biomedical, Waltham, MA). Serum was separated from the third sample and stored at $-4^{\circ} \mathrm{C}$ for analysis of nonesterified fatty acid concentrations (Waco Chemicals USA Inc., Richmond, VA). Concentrations of BHB were determined at collection using a Nova Max ketone strip and a Nova Max Plus reader (Nova Biomedical, Waltham, WA).

Prepartum midstream urine samples following manual stimulation of the space below the vulva were collected 
Table 1. Ingredient composition of diets differing in DCAD and Ca concentration prepartum and the common postpartum diet (\% of DM)

\begin{tabular}{|c|c|c|c|c|c|}
\hline \multirow[b]{3}{*}{ Ingredient } & \multicolumn{5}{|c|}{$\operatorname{Diet}^{1}$} \\
\hline & \multicolumn{2}{|c|}{$\mathrm{NEU}$} & \multicolumn{2}{|c|}{ NEG } & \multirow[b]{2}{*}{ Postpartum } \\
\hline & $1.3 \% \mathrm{Ca}$ & $1.8 \% \mathrm{Ca}$ & $1.3 \% \mathrm{Ca}$ & $1.8 \% \mathrm{Ca}$ & \\
\hline Tifton 85 bermudagrass & 15.00 & 15.00 & 15.00 & 15.00 & 4.32 \\
\hline Corn silage & 43.33 & 43.33 & 43.33 & 43.33 & 38.04 \\
\hline Brewers grains, wet & 9.17 & 9.17 & 9.17 & 9.17 & 10.38 \\
\hline QLF dairy 28 molasses $^{2}$ & 8.33 & 8.33 & 8.33 & 8.33 & 4.32 \\
\hline Ground corn & 2.50 & 2.50 & 2.50 & 2.50 & 12.54 \\
\hline Soybean hulls & & & & & 5.19 \\
\hline Corn gluten feed & & & & & 4.76 \\
\hline Citrus pulp & & & & & 5.19 \\
\hline Cottonseed, whole & & & & & 2.16 \\
\hline Cottonseed hulls ${ }^{3}$ & 4.22 & 2.98 & 1.83 & 0.60 & \\
\hline Soybean meal, $48 \%$ & 5.00 & 5.00 & 5.00 & 5.00 & 1.30 \\
\hline AminoPlus ${ }^{4}$ & 5.00 & 5.00 & 5.00 & 5.00 & 2.59 \\
\hline Prolak $^{5}$ & 3.33 & 3.33 & 3.33 & 3.33 & 3.03 \\
\hline Urea & & & & & 0.17 \\
\hline Mepron $^{6}$ & & & & & 0.05 \\
\hline AjiPro-L ${ }^{7}$ & & & & & 0.26 \\
\hline Megalac $^{8}$ & & & & & 1.73 \\
\hline OmniGen- $\mathrm{AF}^{9}$ & 0.38 & 0.38 & 0.38 & 0.38 & 0.20 \\
\hline Procreatin- $7^{10}$ & 0.03 & 0.03 & 0.03 & 0.03 & 0.01 \\
\hline Rumensin $^{11}$ & 0.33 & 0.33 & 0.33 & 0.33 & 0.26 \\
\hline Salt & 0.13 & 0.13 & 0.13 & 0.13 & 0.35 \\
\hline Sodium sequinate & & & & & 1.04 \\
\hline Calcium carbonate $^{3}$ & 1.27 & 2.50 & 1.17 & 2.40 & 0.86 \\
\hline Magnesium oxide ${ }^{3}$ & 0.18 & 0.18 & & & 0.35 \\
\hline Animate $^{3,12}$ & 1.50 & 1.50 & 4.17 & 4.17 & \\
\hline DCAD Plus ${ }^{13}$ & & & & & 0.52 \\
\hline Dynamate $^{14}$ & & & & & 0.09 \\
\hline Trace mineral-vitamin premix $^{15}$ & 0.30 & 0.30 & 0.30 & 0.30 & 0.30 \\
\hline
\end{tabular}

${ }^{1} \mathrm{NEU}=$ neutral DCAD; NEG $=$ negative DCAD.

${ }^{2}$ Mix contained $48.5 \%$ sugar and $24.0 \%$ CP on a DM basis (Quality Liquid Feeds, Dodgeville, WI).

${ }^{3}$ Ingredients for treatment premix added individually to mixer before feeding.

${ }^{4}$ Ruminally protected soybean meal (Ag Processing Inc., Omaha, NE).

${ }^{5}$ Marine animal RUP supplement (H. J. Baker \& Bros. Inc., Westport, CT).

${ }^{6}$ Ruminally protected methionine (Envonik, Theodore, AL).

${ }^{7}$ Ruminally protected lysine (Ajinomoto, Itasca, IL).

${ }^{8}$ Rumen bypass fat (Arm \& Hammer Animal Nutrition, Princeton, NJ).

${ }^{9}$ Immune modulator (Phibro Animal Health Corp., Teaneck, NJ).

${ }^{10}$ Yeast culture (Phibro Animal Health Corp.).

${ }^{11}$ Monensin (Elanco, Greenfield, IN).

${ }^{12}$ Anionic mineral supplement (Phibro Animal Health Corp.).

${ }^{13}$ Potassium and magnesium sulfate (The Mosaic Company, Plymouth, MN).

${ }^{14}$ Potassium carbonate (Arm \& Hammer Animal Nutrition).

${ }^{15}$ Mineral-vitamin premix contained (DM basis) 29.5\% Ca; $0.42 \% \mathrm{Mg} ; 0.31 \% \mathrm{~S} ; 377 \mathrm{mg} / \mathrm{kg}$ of Co; $3,472 \mathrm{mg} / \mathrm{kg}$ of Cu; $530 \mathrm{mg} / \mathrm{kg}$ of Fe; $388 \mathrm{mg} / \mathrm{kg}$ of I; $23,882 \mathrm{mg} / \mathrm{kg}$ of Mn; $110 \mathrm{mg} / \mathrm{kg}$ of Se; 13,313 mg/kg of Zn; 1,221,966 $\mathrm{IU} / \mathrm{kg}$ of vitamin A; 129,456 IU $/ \mathrm{kg}$ of vitamin D; and 2,817 IU $/ \mathrm{kg}$ of vitamin E.

into specimen cups at $1300 \mathrm{~h}$ at $-21 \mathrm{~d}$ prepartum for $\mathrm{pH}$ analysis (Accumet Basic AB 15, Fisher Scientific, Buford, GA). Additional samples were collected at -14 and $-7 \mathrm{~d}$ prepartum for analysis of $\mathrm{pH}$ (Accumet Basic $\mathrm{AB}$ 15), mineral ( $\mathrm{Ca}, \mathrm{Mg}, \mathrm{Na}, \mathrm{K}$, and $\mathrm{Cl}$ ), and creatinine (Advia 1800 Chemistry System) concentrations. Additionally, $\mathrm{pH}$ was assessed weekly using $\mathrm{pH}$ strips to ensure that the target level of acidification $(5.5-6.0 \mathrm{pH})$ was being met. Data from these $\mathrm{pH}$ checks were not included in the final data set. The fractional excretion of minerals was calculated as follows: (urinary mineral/ serum mineral $) \times($ serum creatinine/urinary creatinine $)$ $\times 100$ (Vander, 1991).

After calving, cows were milked 3 times per day at 0800, 1600, and $2400 \mathrm{~h}$. Milk weights were electronically recorded each milking (Alpro, Deleval, Kansas City, MO) and summed daily. Milk samples were collected once each week from 3 consecutive milkings. Samples 
were refrigerated and shipped for next-day delivery to Dairy One Cooperative (Ithaca, NY) for analysis of fat, protein, lactose, MUN, and SCC using a Foss 400 instrument (Foss North America, Eden Prairie, MN) as described by AOAC International (2000).

Prepartum data were restricted to the $21 \mathrm{~d}$ before actual calving, and the sample collection date was adjusted accordingly $( \pm 3 \mathrm{~d})$. Data from 10 cows were excluded from the data analysis because of abortion after pregnancy diagnosis $(\mathrm{n}=2)$, injury $(\mathrm{n}=3)$, left displaced abomasum $(\mathrm{n}=1)$, retained placenta and being moved to the hospital herd $(\mathrm{n}=1)$, and failure to retrain to the Calan gate after calving $(\mathrm{n}=3)$. Distribution of cows removed from the trial across treatments was NEG-1.3\% Ca, $\mathrm{n}=3$; NEG-1.8\% Ca, $\mathrm{n}=2$; NEU-1.3\% Ca, $\mathrm{n}=3$; and NEU-1.8\% Ca, $\mathrm{n}=2$. Four cows beginning their fourth lactation-1 in each treatment combination - experienced clinical hypocalcemia. The 0-d blood samples from these cows were collected and included in the data analysis, but samples collected after treatment for hypocalcemia were not included in the final data analysis.

Data were subjected to repeated ANOVA using MIXED procedures of SAS (SAS Institute, Cary, NC). Prepartum and postpartum data were analyzed separately. The model included block, DCAD treatment, Ca treatment, interaction of DCAD and Ca, time (day or week), and the 2- and 3-way interactions of time and treatments. The REPEATED statement was used for all measurements taken at multiple time points. Four covariance structures were tested for each model as outlined by Littell et al. (1998), and the model with the lowest Akaike information criterion was selected. The first-order autoregressive covariance structure resulted in the lowest Akaike information criterion and was used in the final analysis. Previous lactation 305-d mature equivalent milk, fat, and protein yields along with average lactation SCC were used as covariates in the analysis of production data. Significance was declared at $P$ $<0.05$, and a trend was declared when $P \geq 0.05$ and $<0.1$. When an interaction was detected, the PDIFF option was used in the LSMEANS statement for mean separation.

\section{RESULTS}

Chemical composition of experimental prepartum diets and the common postpartum diet is presented in Table 2. The DCAD $[(\mathrm{Na}+\mathrm{K})-(\mathrm{Cl}+\mathrm{S})]$ was calculated to be -2.37 and $-21.18 \mathrm{mEq} / 100 \mathrm{~g}$ of $\mathrm{DM}$ for NEU and NEG, respectively, and Ca concentrations were 1.3 or $1.8 \%$ DM. Other than formulated differences in DCAD and Ca, the chemical composition of the diets was similar.

No differences were observed due to DCAD, Ca, or interaction of treatments in BW or BCS throughout the trial. Prepartum BW and BCS averaged $754.8 \mathrm{~kg}$ and 3.36, respectively. Postpartum BW at calving and at 21 and 63 DIM averaged 707.2, 654.9, and $638.3 \mathrm{~kg}$, respectively. Corresponding BCS at calving and at 21 and 63 DIM were $3.18,3.03$, and 2.92, respectively.

Prepartum DMI was lowest for cows fed NEG $(P=$ 0.0096) compared with cows fed NEU (14.2 and 16.0 $\mathrm{kg} / \mathrm{d}$, respectively) and for cows fed $1.8 \% \mathrm{Ca}(P=$

Table 2. Chemical composition (\% of DM unless noted) of diets differing in DCAD and Ca concentration prepartum and the common postpartum diet (mean $\pm \mathrm{SD}$ )

\begin{tabular}{|c|c|c|c|c|c|}
\hline \multirow[b]{3}{*}{ Item } & \multicolumn{5}{|c|}{$\operatorname{Diet}^{1}$} \\
\hline & \multicolumn{2}{|c|}{$\mathrm{NEU}$} & \multicolumn{2}{|c|}{ NEG } & \multirow[b]{2}{*}{ Postpartum } \\
\hline & $1.3 \% \mathrm{Ca}$ & $1.8 \% \mathrm{Ca}$ & $1.3 \% \mathrm{Ca}$ & $1.8 \% \mathrm{Ca}$ & \\
\hline DM, \% & $52.5 \pm 4.4$ & $52.7 \pm 3.8$ & $53.2 \pm 3.9$ & $53.8 \pm 3.9$ & $54.7 \pm 3.7$ \\
\hline $\mathrm{CP}$ & $21.4 \pm 1.3$ & $21.2 \pm 1.5$ & $21.8 \pm 1.0$ & $21.3 \pm 1.3$ & $17.4 \pm 1.4$ \\
\hline $\mathrm{ADF}$ & $17.9 \pm 0.6$ & $17.8 \pm 1.8$ & $18.9 \pm 1.5$ & $18.1 \pm 0.5$ & $18.3 \pm 2.3$ \\
\hline $\mathrm{NDF}$ & $38.1 \pm 1.7$ & $37.3 \pm 1.2$ & $39.9 \pm 1.2$ & $40.1 \pm 1.2$ & $36.5 \pm 3.0$ \\
\hline $\mathrm{EE}^{2}$ & $2.9 \pm 0.6$ & $2.3 \pm 0.2$ & $2.9 \pm 0.5$ & $2.7 \pm 0.6$ & $5.6 \pm 1.6$ \\
\hline Ash & $8.5 \pm 0.4$ & $9.7 \pm 0.4$ & $8.7 \pm 0.4$ & $9.9 \pm 0.4$ & $7.5 \pm 0.5$ \\
\hline $\mathrm{Ca}$ & $1.31 \pm 0.07$ & $1.81 \pm 0.07$ & $1.30 \pm 0.07$ & $1.80 \pm 0.07$ & $1.05 \pm 0.08$ \\
\hline $\mathrm{P}$ & $0.41 \pm 0.01$ & $0.40 \pm 0.01$ & $0.42 \pm 0.01$ & $0.42 \pm 0.01$ & $0.42 \pm 0.02$ \\
\hline $\mathrm{Mg}$ & $0.50 \pm 0.06$ & $0.51 \pm 0.06$ & $0.53 \pm 0.01$ & $0.54 \pm 0.06$ & $0.38 \pm 0.02$ \\
\hline $\mathrm{K}$ & $1.60 \pm 0.08$ & $1.59 \pm 0.08$ & $1.60 \pm 0.08$ & $1.59 \pm 0.08$ & $1.46 \pm 0.05$ \\
\hline $\mathrm{Na}$ & $0.11 \pm 0.04$ & $0.11 \pm 0.04$ & $0.12 \pm 0.04$ & $0.12 \pm 0.04$ & $0.42 \pm 0.07$ \\
\hline $\mathrm{S}$ & $0.42 \pm 0.03$ & $0.42 \pm 0.03$ & $0.57 \pm 0.12$ & $0.57 \pm 0.03$ & $0.26 \pm 0.01$ \\
\hline $\mathrm{Cl}$ & $0.77 \pm 0.09$ & $0.77 \pm 0.09$ & $1.11 \pm 0.09$ & $1.11 \pm 0.09$ & $0.41 \pm 0.03$ \\
\hline $\mathrm{DCAD}^{3}$ & $-2.30 \pm 3.23$ & $-2.45 \pm 3.23$ & $-21.11 \pm 3.23$ & $-21.26 \pm 3.23$ & $27.10 \pm 2.34$ \\
\hline
\end{tabular}


Table 3. Prepartum ( -28 through -2 d) parameters of the serum biochemical analysis and mineral concentrations of cows fed diets differing in prepartum DCAD and Ca concentrations

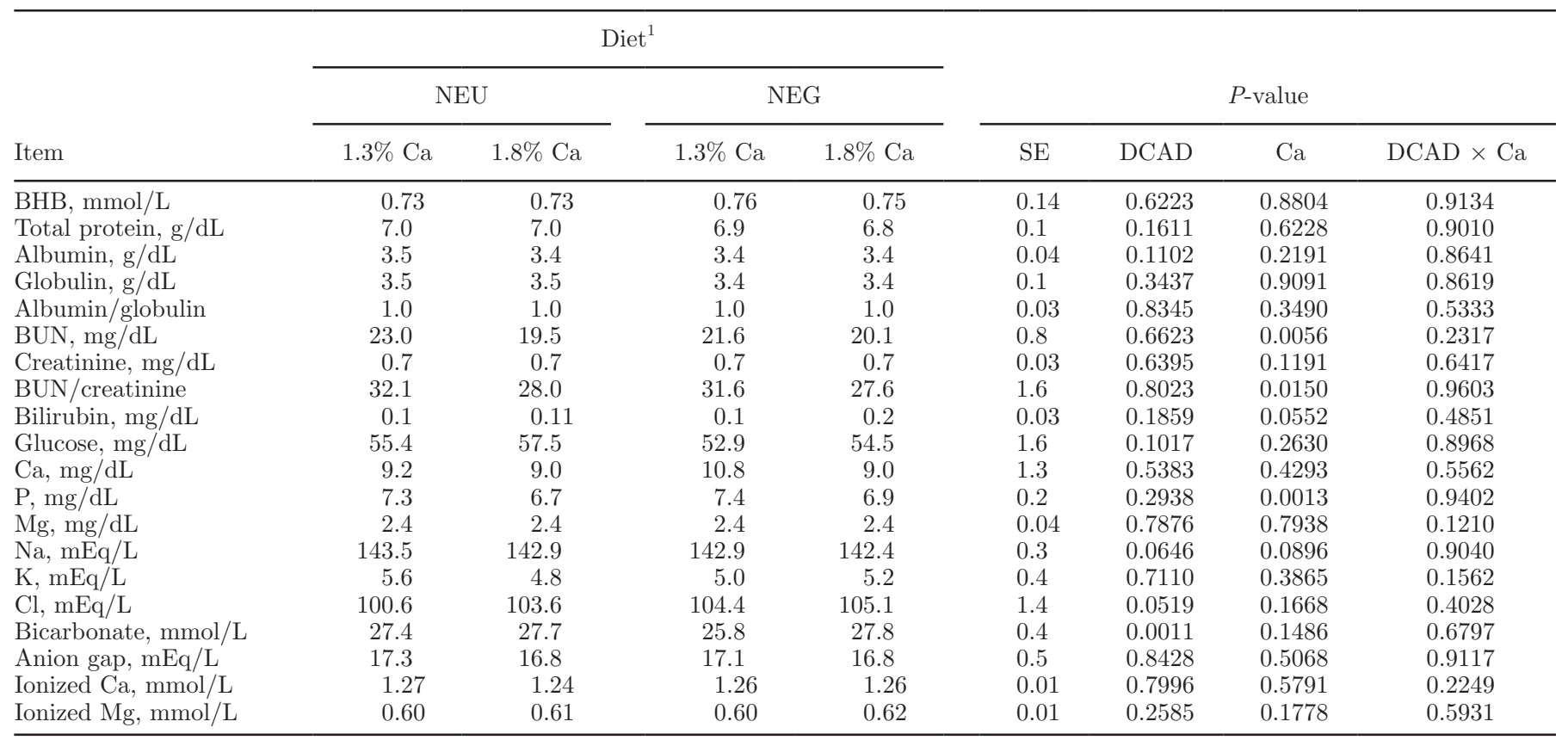

${ }^{1} \mathrm{NEU}=$ neutral DCAD; NEG = negative DCAD.

$0.0038)$ compared with cows fed $1.3 \% \mathrm{Ca}(14.0$ and $16.2 \mathrm{~kg} / \mathrm{d}$, respectively). When expressed as a percentage of BW, DMI was also lower for cows fed NEG $(P$ $=0.0051)$ compared with NEU (1.94 and $2.13 \%$ of BW, respectively) or cows fed $1.8 \% \mathrm{Ca}(P=0.0046)$ compared with $1.3 \% \mathrm{Ca}$ (1.89 and $2.18 \%$ of BW, respectively).

Prepartum serum metabolites are presented in Table 3. Cows fed NEG tended to have lower concentrations of $\mathrm{Na}(142.6$ and $143.3 \mathrm{mEq} / \mathrm{L}, \mathrm{SE} \pm 0.2, P=0.0646)$ and lower bicarbonate $(26.2$ and $27.6 \mathrm{mmol} / \mathrm{L}, \mathrm{SE} \pm$ $0.3, P=0.0011)$ but tended to have higher $\mathrm{Cl}(104.8$ and $102.1 \mathrm{mEq} / \mathrm{L}, \mathrm{SE} \pm 0.9, P=0.0519)$ compared with cows fed NEU. Increasing dietary Ca from $1.3 \%$ to $1.8 \%$ reduced serum $\mathrm{P}(7.3$ and $6.8 \mathrm{mg} / \mathrm{dL}, \mathrm{SE} \pm 0.1$, $P=0.0013)$, BUN $(22.3$ and $19.8 \mathrm{mg} / \mathrm{dL}, \mathrm{SE} \pm 0.6, P$ $=0.0056)$, and BUN:creatinine ratio (31.9 and 27.8, SE $\pm 1.1, P=0.0150)$, respectively.

Plasma bicarbonate tended $(P=0.0599)$ to be lower for cows fed NEG at -21 and $-14 \mathrm{~d}$ prepartum compared with cows fed NEU but was similar at -7 and -2 d prepartum (data not shown). Albumin concentrations were higher at -7 and $-2 \mathrm{~d}$ before calving for cows fed $1.3 \%$ Ca compared with cows fed $1.8 \%$ Ca, resulting in an interaction $(P=0.0297$, Figure 1). Plasma Na was higher for cows fed $1.3 \%$ Ca compared with cows fed $1.8 \% \mathrm{Ca}$ at $-21 \mathrm{~d}$ prepartum but was not different throughout the remainder of the prepartum period, resulting in an interaction $(P=0.0363$, Figure 2$)$.
Urine $\mathrm{pH}$ was lower $(P<0.0001)$ for cows fed NEG compared with cows fed NEU and averaged 6.03 and 7.05 ( $\mathrm{SE} \pm 0.1$ ), respectively (Table 4). Urine $\mathrm{pH}$ also tended to be lower $(P=0.0628)$ for cows fed $1.8 \%$ Ca compared with cows fed $1.3 \% \mathrm{Ca}$ (6.33 and 6.75, respectively; $\mathrm{SE} \pm 0.1)$. Fractional excretion of $\mathrm{Ca}(P$ $=0.0156)$ and $\mathrm{Cl}(P<0.0001)$ was higher for cows fed NEG compared with cows fed NEU, whereas fractional excretion of $\mathrm{Na}(P=0.0262)$ and $\mathrm{K}(P=0.0375)$ was higher for cows fed $1.3 \%$ Ca compared with cows fed $1.8 \%$ Ca.

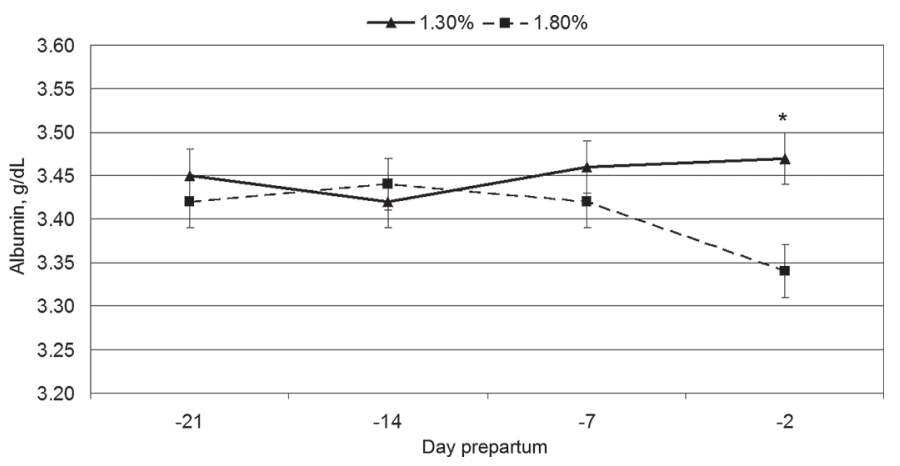

Figure 1. Prepartum albumin concentrations of cows fed prepartum diets supplemented with 1.3 or $1.8 \% \mathrm{Ca}(\mathrm{Ca} \times$ days prepartum, $P$ $=0.0297)$. Asterisks $(*)$ indicate time points where treatment means differ $(P<0.05)$. Error bars represent SE. 
Table 4. Prepartum ( -28 through $-2 \mathrm{~d})$ urine $\mathrm{pH}$ and fractional excretion of minerals in cows fed diets differing in prepartum DCAD and Ca concentrations

\begin{tabular}{|c|c|c|c|c|c|c|c|c|}
\hline Item & \multicolumn{4}{|c|}{ Diet $^{1}$} & $\mathrm{SE}$ & \multicolumn{3}{|c|}{$P$-value } \\
\hline $\begin{array}{l}\text { Urine } \\
\text { pH } \\
\text { Fractional excretion. \% }\end{array}$ & 7.45 & 6.66 & 6.05 & 6.01 & 0.21 & $<0.0001$ & 0.0628 & 0.0973 \\
\hline
\end{tabular}

${ }^{1} \mathrm{NEU}=$ neutral DCAD; NEG = negative DCAD.

Postpartum blood metabolites from 0 to 14 DIM are shown in Table 5 . Concentrations of plasma total protein $(6.5$ and $6.8 \mathrm{~g} / \mathrm{dL}, \mathrm{SE} \pm 0.1, P=0.0033)$, albumin (3.5 and $3.6 \mathrm{~g} / \mathrm{dL}, \mathrm{SE} \pm 0.1, P=0.0157)$, creatinine $(0.7$ and $0.8 \mathrm{mg} / \mathrm{dL}, \mathrm{SE} \pm 0.1, P=0.0213), \mathrm{Mg}(2.2$ and $2.4 \mathrm{mg} / \mathrm{dL}, \mathrm{SE} \pm 0.1, P=0.0042)$, and $\mathrm{iMg}(0.58$ and $0.61 \mathrm{mg} / \mathrm{dL}, \mathrm{SE} \pm 0.01, P=0.0028)$ were lower and $\mathrm{Na}$ was higher $(142.0$ and $141.4 \mathrm{mEq} / \mathrm{L}, \mathrm{SE} \pm 0.2$, $P=0.0 .0463)$ for cows fed NEG compared with cows fed NEU. Concentrations of BUN (15.0 and $17.0 \mathrm{mg} /$ $\mathrm{dL}, \mathrm{SE} \pm 0.7, P=0.0531)$ tended to be higher for NEG compared with NEU. Concentrations of albumin were higher for cows fed $1.3 \%$ Ca compared with cows fed $1.8 \% \mathrm{Ca}(3.5$ and $3.4 \mathrm{~g} / \mathrm{dL}$, respectively; $\mathrm{SE} \pm 0.1)$. An interaction $(P=00063)$ of DCAD and Ca was observed for creatinine that was higher for cows fed NEG-1.3\% Ca compared with the other treatments. An interaction of DCAD and DIM was observed for plasma bicarbonate $(P=0.0229)$ because of higher concentrations at 3 DIM and lower concentrations at 14 DIM for cows fed NEU compared with cows fed NEG (Figure 3). Plasma

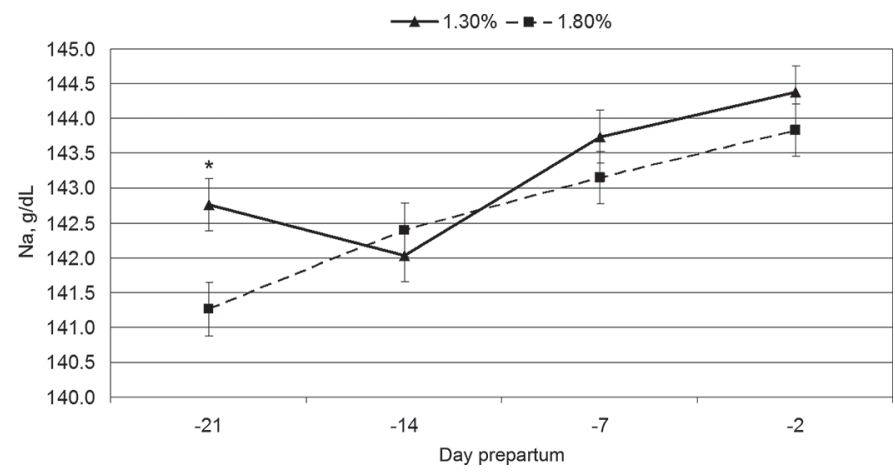

Figure 2. Prepartum sodium concentrations of cows fed prepartum diets supplemented with 1.3 or $1.8 \% \mathrm{Ca}(\mathrm{Ca} \times$ days prepartum, $P=$ $0.0363)$. Asterisks $(*)$ indicate time points where treatment means differ $(P<0.05)$. Error bars represent SE.
iMg was higher $(P=0.0139)$ at 1,2 , and 14 DIM for cows fed NEU compared with cows fed NEG, resulting in a DCAD by DIM interaction (Figure 4). An interaction of Ca and DIM was observed for plasma Ca $(P=$ $0.0279)$ due to higher concentrations at 1 DIM for cows fed $1.8 \%$ Ca compared with cows fed $1.3 \%$ Ca (Figure 5). Plasma $\mathrm{Cl}$ concentrations were higher at 1 DIM and lower at 14 DIM for cows fed $1.3 \%$ Ca compared with cows fed $1.8 \% \mathrm{Ca}(P=0.0164$, Figure 6$)$. Anion gap concentrations were lower at 1 DIM and higher at 14 DIM for cows fed $1.3 \%$ Ca compared with cows fed $1.8 \% \mathrm{Ca}$, resulting in a Ca by DIM interaction $(P=$ 0.0302, Figure 7).

Postpartum DMI was not different among DCAD or Ca treatments and averaged $23.1 \pm 0.9 \mathrm{~kg} / \mathrm{d}$ (Table 6 ). No differences were observed in daily milk yield among treatments, but there was an interaction for DCAD and DIM $(P=0.0125$, Figure 8$)$ as milk yield of cows fed NEG was $2.6 \mathrm{~kg} / \mathrm{d}$ higher beginning approximately 45 DIM through the end of the trial compared with cows fed NEU. No differences in milk component percentage or yield were observed (Table 6). An interaction of Ca and week was observed for MUN that was higher at 5 wk and lower at 6 wk for cows fed $1.8 \%$ Ca compared with cows fed $1.3 \% \mathrm{Ca}(P=0.0412$, Figure 9$)$.

\section{DISCUSSION}

No differences were observed in pre- or postpartum BW or BCS between treatments. Prepartum DMI was affected by both DCAD and Ca, where lower DCAD or higher Ca supplementation decreased DMI. This is consistent with previous observations (Oetzel, 1993; Moore et al., 2000; Charbonneau et al., 2006) in which acidogenic diets decreased prepartum DMI. Miller (1983) and Beede et al. (2001) reported a similar decrease in DMI with higher inclusion of $\mathrm{Ca}$ and concluded that the additional dietary mineral content decreased pal- 
Table 5. Postpartum parameters of the serum biochemical analysis and mineral concentrations from 0 to 14 DIM of cows fed diets differing in prepartum DCAD and Ca concentrations

\begin{tabular}{|c|c|c|c|c|c|c|c|c|}
\hline \multirow{2}{*}{ Item } & \multicolumn{4}{|c|}{$\operatorname{Diet}^{1}$} & \multirow{2}{*}{$\mathrm{SE}$} & \multirow{2}{*}{\multicolumn{3}{|c|}{$P$-value }} \\
\hline & \multicolumn{2}{|c|}{ NEU } & \multicolumn{2}{|c|}{ NEG } & & & & \\
\hline $\mathrm{NEFA}^{2}{ }^{2} \mathrm{mEq} / \mathrm{L}$ & 0.95 & 0.99 & 1.13 & 1.04 & 0.22 & 0.1118 & 0.7546 & 0.3825 \\
\hline BHB, mmol/L & 1.2 & 1.1 & 1.2 & 1.4 & 0.1 & 0.1939 & 0.5586 & 0.2697 \\
\hline Total protein, g/dL & 6.9 & 6.9 & 6.6 & 6.6 & 0.1 & 0.0033 & 0.6998 & 0.5807 \\
\hline Albumin/globulin & 1.1 & 1.0 & 1.2 & 1.1 & 0.1 & 0.4749 & 0.1666 & 0.4724 \\
\hline BUN, mg/dL & 18.6 & 15.3 & 14.9 & 15.1 & 1.0 & 0.0531 & 0.1447 & 0.0813 \\
\hline Creatinine, mg/dL & $0.9^{\mathrm{a}}$ & $0.7^{\mathrm{b}}$ & $0.7^{\mathrm{b}}$ & $0.7^{\mathrm{b}}$ & 0.04 & 0.0213 & 0.3644 & 0.0106 \\
\hline BUN/creatinine & 21.8 & 21.8 & 24.6 & 21.2 & 1.5 & 0.4662 & 0.2745 & 0.2650 \\
\hline Bilirubin, mg/dL & 0.4 & 0.4 & 0.5 & 0.5 & 0.05 & 0.2272 & 0.3568 & 0.9872 \\
\hline Glucose, mg/dL & 53.4 & 54.1 & 52.6 & 48.8 & 3.2 & 0.3425 & 0.6359 & 0.5011 \\
\hline $\mathrm{Ca}, \mathrm{mg} / \mathrm{dL}$ & 8.4 & 8.5 & 8.3 & 8.5 & 0.1 & 0.5391 & 0.3070 & 0.7297 \\
\hline Bicarbonate, mmol/L & 29.7 & 30.2 & 30.1 & 29.9 & 0.4 & 0.8012 & 0.7769 & 0.2818 \\
\hline Anion gap, mEq/L & 16.2 & 16.0 & 16.5 & 16.6 & 0.4 & 0.2670 & 0.8339 & 0.7489 \\
\hline Ionized Ca, mmol/L & 1.18 & 1.27 & 1.16 & 1.23 & 0.05 & 0.5351 & 0.1256 & 0.8221 \\
\hline Ionized Mg, mmol/L & 0.61 & 0.60 & 0.57 & 0.58 & 0.05 & 0.0028 & 0.7061 & 0.3809 \\
\hline
\end{tabular}

${ }^{\text {a.b }}$ Means within a row with different superscripts differ $(P<0.05)$.

${ }^{1} \mathrm{NEU}=$ neutral DCAD; NEG $=$ negative DCAD.

${ }^{2}$ Nonesterified fatty acid (NEFA) concentrations were measured only on $0,1,2$, and 3 DIM.

atability. Although differences in DMI were observed in the current trial, DMI for cows in all treatments was above the minimum recommended by NRC (2001). Because dietary $\mathrm{Ca}$ concentrations were higher than planned and DMI was higher than predicted, Ca intake averaged 226, 268, 196, and $234 \mathrm{~g} / \mathrm{d}$ for NEU-1.3\% Ca, NEU-1.8\% Ca, NEG-1.3\% Ca, and NEG-1.8\% Ca, respectively. Postpartum DMI was not different among treatments, which is in contrast with the reports of

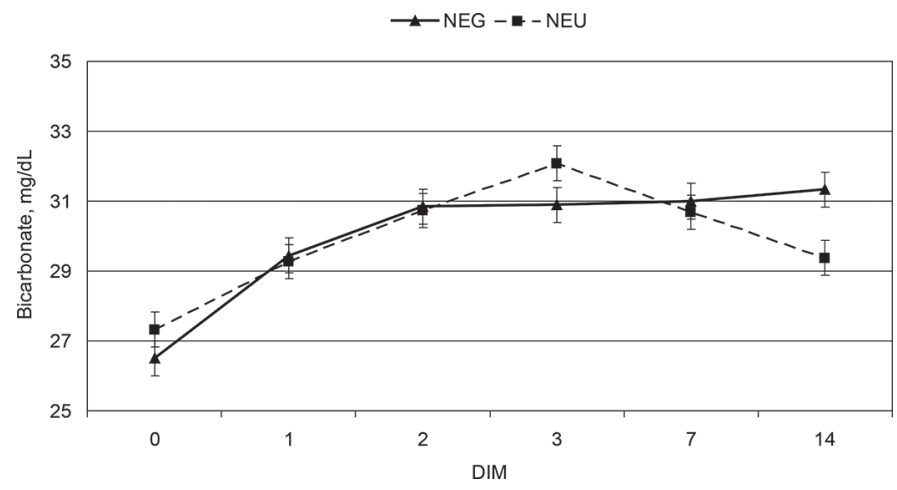

Figure 3. Plasma bicarbonate concentrations on 0 to 14 DIM of cows fed prepartum diets with a DCAD of -21 (NEG) or -2 (NEU) $\mathrm{mEq} / 100 \mathrm{~g}$ of DM $(\mathrm{DCAD} \times \mathrm{DIM}, P=0.0229)$. Error bars represent SE.
DeGroot et al. (2010) and Leno et al. (2017), in which prepartum acidogenic diets improved postpartum DMI.

Feeding NEG resulted in lower urine $\mathrm{pH}$ compared with NEU. This is consistent with previous research in which increasing dietary acidogenicity to create a mild compensated metabolic acidosis decreased urine pH (Jardon, 1995; Vagnoni and Oetzel, 1998; Moore et al., 2000; Charbonneau et al., 2006). We also observed a tendency for lower urine $\mathrm{pH}$ for $1.8 \%$ Ca compared

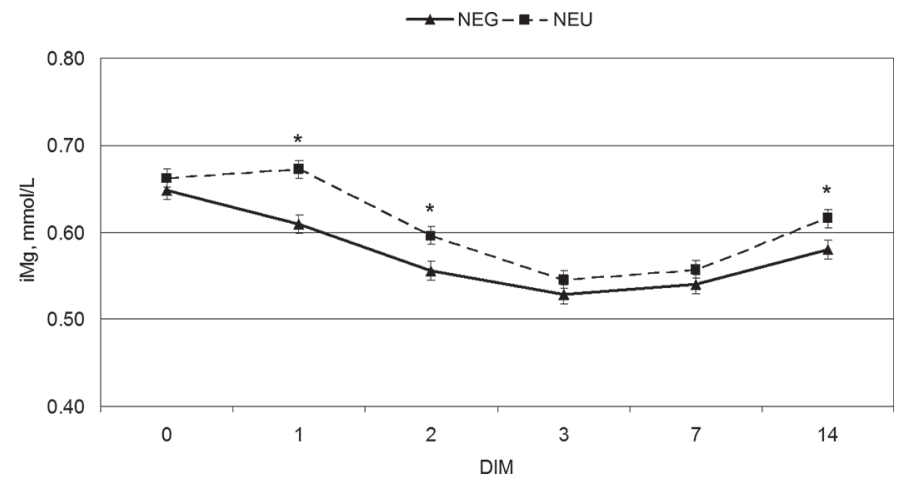

Figure 4. Plasma ionized $\mathrm{Mg}$ (iMg) concentrations on 0 to 14 DIM of cows fed prepartum diets with a DCAD of -21 (NEG) or -2 $(\mathrm{NEU}) \mathrm{mEq} / 100 \mathrm{~g}$ of DM $(\mathrm{DCAD} \times \mathrm{DIM}, P=0.0139)$. Asterisks $(*)$ indicate time points where treatment means differ $(P<0.05)$. Error bars represent SE. 


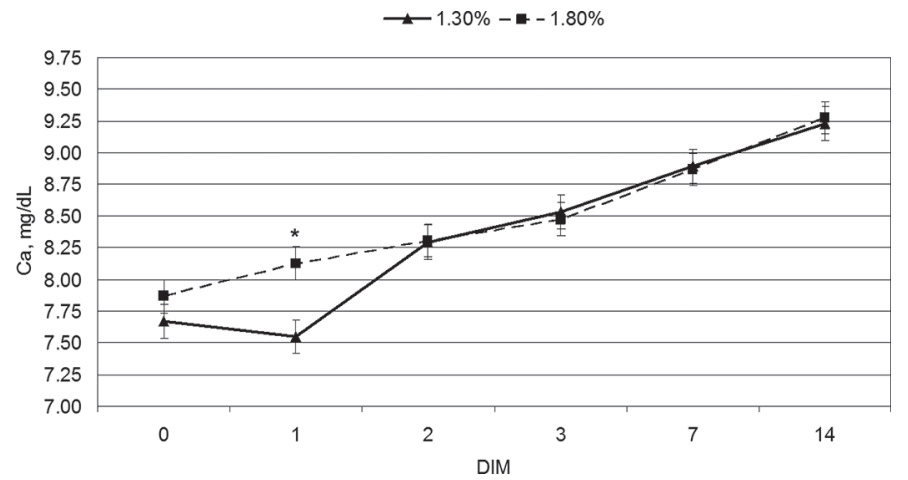

Figure 5. Plasma Ca concentrations on 0 to 3 DIM of cows fed prepartum diets supplemented with 1.3 or $1.8 \% \mathrm{Ca}(\mathrm{Ca} \times \mathrm{DIM}, P=$ $0.0279)$. Asterisks $(*)$ indicate time points where treatment means differ $(P<0.05)$. Error bars represent SE.

with $1.3 \% \mathrm{Ca}$. Calcium is a cation, which would increase metabolic alkalosis and should increase urine $\mathrm{pH}$. The reason for the lower $\mathrm{pH}$ is not apparent because there were no differences in concentrations of anions in the blood or urine. Feeding NEG resulted in greater fractional excretion of $\mathrm{Ca}$ and $\mathrm{Cl}$ compared with NEU. These results are consistent with the observations of Leno et al. (2017) where Ca excretion increased as urine $\mathrm{pH}$ decreased. The anionic supplement used to acidify the diets contained high concentrations of $\mathrm{Cl}$, resulting in increased plasma $\mathrm{Cl}$ concentrations and higher fractional excretion of $\mathrm{Cl}$.

Prepartum intake of $\mathrm{Ca}$ for all treatments was higher than planned and ranged from 196 to $265 \mathrm{~g} / \mathrm{d}$ due to higher DMI for NEG and higher than planned concentrations of $\mathrm{Ca}$ in all diets. Oetzel (1991) reported that extremes in dietary Ca concentrations were beneficial in preventing milk fever and that intermediate concentrations (near $1.16 \%$ of DM) were associated with higher incidence rates; however, neither DCAD nor Ca intake

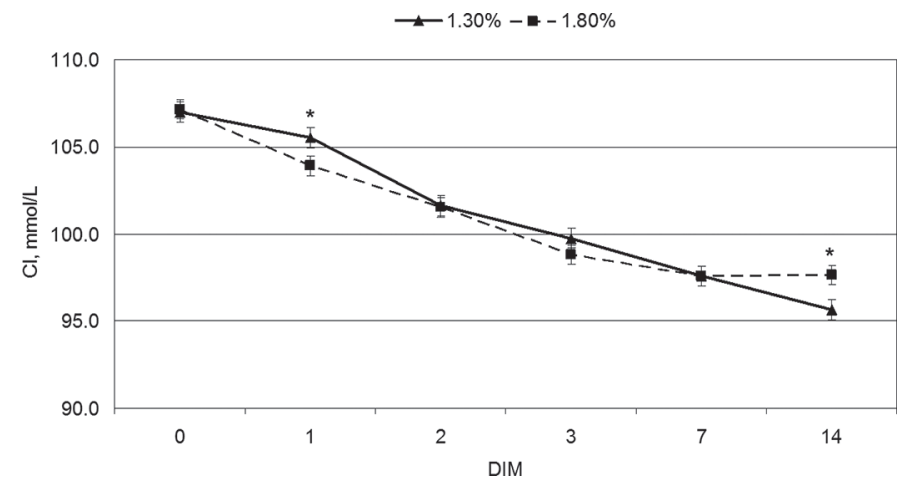

Figure 6. Plasma $\mathrm{Cl}$ concentrations on 0 to 14 DIM of cows fed prepartum diets supplemented with 1.3 or $1.8 \% \mathrm{Ca}(\mathrm{Ca} \times \mathrm{DIM}, P=$ $0.0164)$. Asterisks $(*)$ indicate time points where treatment means differ $(P<0.05)$. Error bars represent SE.

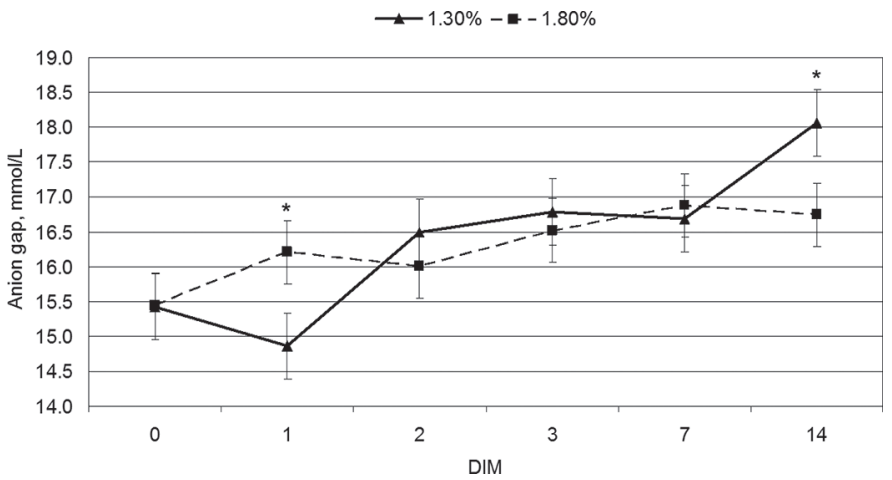

Figure 7. Plasma anion gap concentrations on 0 to 14 DIM of cows fed prepartum diets supplemented with 1.3 or $1.8 \% \mathrm{Ca}(\mathrm{Ca} \times \mathrm{DIM}, P$ $=0.0302)$. Asterisks $(*)$ indicate time points where treatment means differ $(P<0.05)$. Error bars represent SE.

were included in their meta-analysis. Beede et al. (2001) fed prepartum diets containing $0.47 \%$ to $1.95 \%$ Ca with or without supplemental $\mathrm{Cl}$ to Holstein cows and heifers and reported increased $\mathrm{iCa}$ for diets with supplemental $\mathrm{Cl}$, but no differences were observed among dietary $\mathrm{Ca}$ concentrations. In our current trial, feeding $1.8 \% \mathrm{Ca}$ compared with $1.3 \% \mathrm{Ca}$ increased plasma Ca at $1 \mathrm{DIM}$ ( 8.1 vs. $7.5 \mathrm{mg} / \mathrm{dL}$, respectively, Figure 7 ) but did not improve plasma $\mathrm{Ca}$ at any other time or increase iCa. This time point is important because it falls within the 12 to $24 \mathrm{~h}$ postpartum when average blood $\mathrm{Ca}$ concentrations are lowest in multiparous cows (Goff, 2008). Four cases of hypocalcemia - 1 in each treatment combination - were observed within this time frame in cows beginning their fourth lactation. Venjakob et al. (2017) reported increased clinical hypocalcemia with parity, which averaged $16.1 \%$ for cows beginning their fourth or greater lactation. Parity is the key factor that predisposes cows to developing hypocalcemia (van Mosel et al., 1993); however, the cases in our trial occurred in August after a period of extreme heat stress, which would also have contributed to a greater probability of hypocalcemia. Shire and Beede (2013) reported that a pregnant 726-kg Holstein requires approximately 11 $\mathrm{g} / \mathrm{d}$ of absorbed $\mathrm{Ca}$, which would be approximately 20 to $30 \mathrm{~g} / \mathrm{d}$ or $1.0 \%$ Ca DM based on current NRC (2001) recommendations. When acidogenic diets are fed, NRC (2001) reported that providing more than $150 \mathrm{~g}$ of $\mathrm{Ca} / \mathrm{d}$ has successfully prevented hypocalcemia (Oetzel et al., 1988; Beede et al., 1991). Under the conditions of this trial, our results do not indicate any additional benefit in Ca status for feeding more than $1.3 \%$ Ca prepartum.

Increased dietary Ca decreased $\mathrm{P}$ absorption (Jacobson et al., 1972), which explains the lower plasma $\mathrm{P}$ concentrations. Concentrations of $\mathrm{Mg}$ were within the normal range postpartum $(1.6-3.6 \mathrm{mg} / \mathrm{dL})$, but both $\mathrm{Mg}$ and $\mathrm{iMg}$ were $5 \%$ higher for cows fed NEU com- 
Table 6. Dry matter intake and milk yield and composition of cows fed diets differing in prepartum DCAD and Ca concentrations

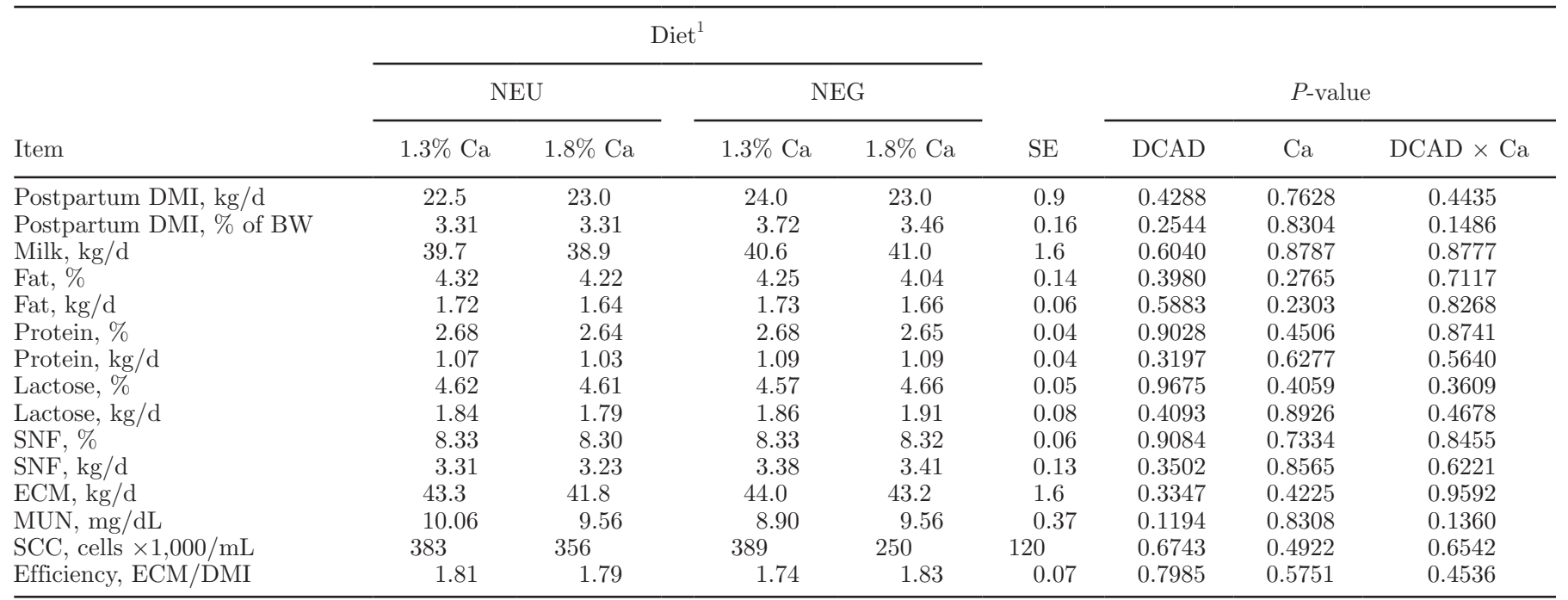

${ }^{1} \mathrm{NEU}=$ neutral DCAD; NEG = negative DCAD.

pared with NEG. Concentrations of iMg were higher at 1,2, and 14 DIM for cows fed NEU compared with NEG (Figure 6). In contrast, dietary Mg concentrations were slightly higher for NEG compared with NEU ( $0.54 \%$ and $0.51 \%$ of DM for NEG and NEU, respectively). Venjakob et al. (2017) reported a negative relationship between serum $\mathrm{Ca}$ and $\mathrm{Mg}$ in cows immediately postpartum; however, serum $\mathrm{Ca}$ and iCa were not different in our trial. The difference observed for $\mathrm{Mg}$ and iMg may be due to differences in $\mathrm{Mg}$ homeostatic mechanisms in response to parathyroid hormone, which would have been stimulated more by feeding NEG. Goff
(2008) reported that parathyroid hormone increased the threshold for renal excretion of $\mathrm{Mg}$, resulting in increased serum $\mathrm{Mg}$ when dietary $\mathrm{Mg}$ is not limiting.

Interactions of day prepartum and $\mathrm{Ca}$ were observed for $\mathrm{Na}$ (Figure 3) and urinary creatinine (Figure 4). Sodium concentrations were higher at $-21 \mathrm{~d}$ prepartum for cows fed $1.3 \%$ Ca compared with those fed $1.8 \%$ $\mathrm{Ca}$. The reason for this difference may have been due to variation in adaptation to diets that were abruptly introduced at $-28 \mathrm{~d}$ prepartum. The change in urinary creatinine was evident at $-2 \mathrm{~d}$ prepartum and possibly reflects differences in urinary volume. Previous

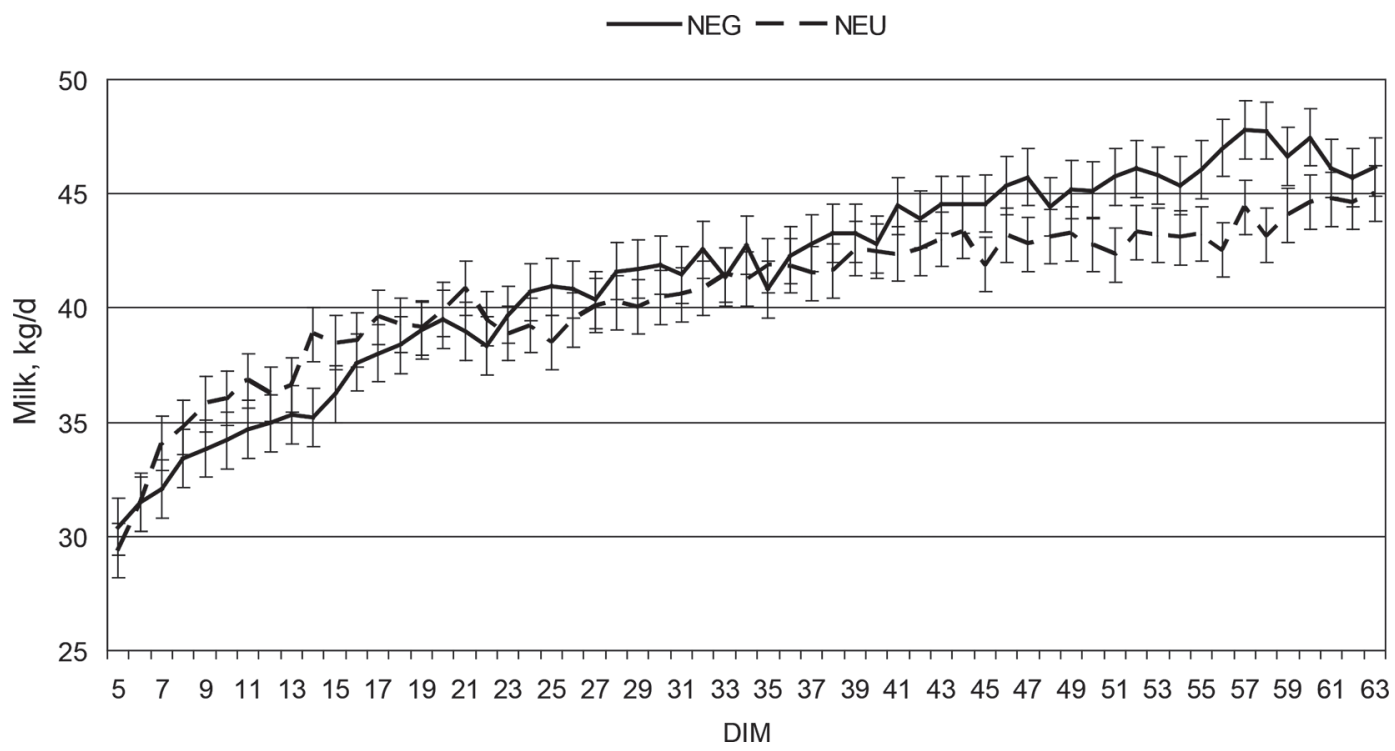

Figure 8. Daily milk yield of cows fed prepartum diets with a DCAD of -21 (NEG) or $-2(\mathrm{NEU}) \mathrm{mEq} / 100 \mathrm{~g}$ of DM $(P=0.0096)$. Asterisks $(*)$ indicate time points where treatment means differ $(P<0.05)$. Error bars represent SE. 


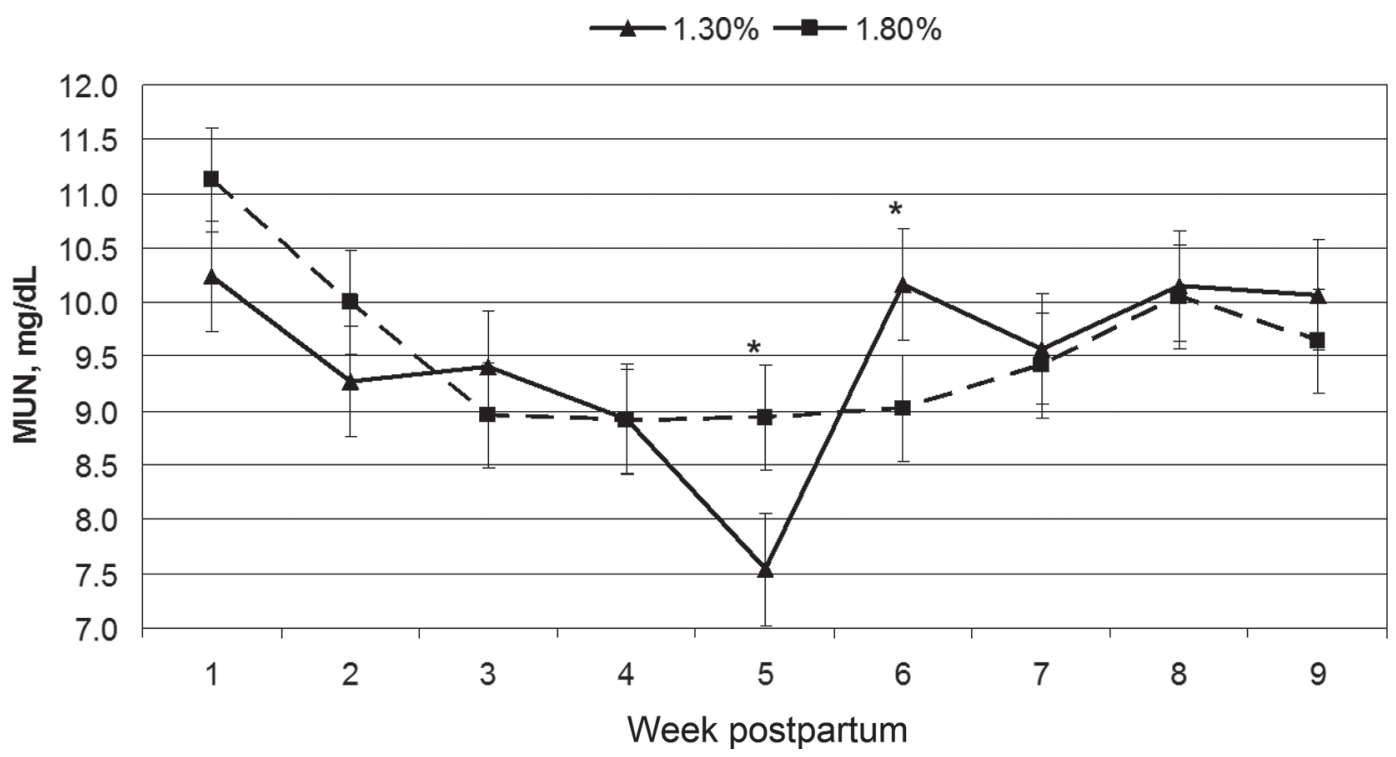

Figure 9. Concentrations of MUN for cows fed prepartum diets supplemented with 1.3 or $1.8 \% \mathrm{Ca}(P=0.0412)$. Asterisks $(*)$ indicate time points where treatment means differ $(P<0.05)$. Error bars represent SE.

researchers have reported positive correlations of bicarbonate and DCAD (Wildman et al., 2007 a, b), which explains the higher bicarbonate prepartum observed for NEU compared with NEG in our current trial. All cows were fed the same diet postpartum with a DCAD of $27.1 \mathrm{mEq} / 100 \mathrm{~g}$ of $\mathrm{DM}$, so the reason for the higher bicarbonate concentrations observed on 3 DIM for NEU is not readily apparent. The observed interaction of $\mathrm{Ca}$ and DIM for $\mathrm{Cl}$ is the primary reason for the inverse interaction observed for anion gap, as higher $\mathrm{Cl}$ concentrations would reduce the anion gap.

Changes in protein status are reflected by changes in creatinine, total protein, albumin, and creatine kinase concentrations (Van Saun, 2006). In our current trial, prepartum BUN and BUN:creatinine was lower for cows fed $1.8 \%$ Ca compared with $1.3 \% \mathrm{Ca}$, which is most likely the result of slightly lower dietary protein intake associated with the lower DMI observed for cows fed $1.8 \% \mathrm{Ca}$ (3.5 and $3.0 \mathrm{~kg} / \mathrm{d}$ of $\mathrm{CP}$ intake for $1.3 \%$ and $1.8 \% \mathrm{Ca}$, respectively). Prepartum albumin concentrations decreased for cows fed $1.8 \% \mathrm{Ca}$ at $-2 \mathrm{~d}$ prepartum, whereas albumin concentrations were maintained for cows fed $1.3 \%$ Ca. Postpartum concentrations of total protein, albumin, BUN, and creatinine were higher for cows fed NEU compared with NEG, which would suggest differences in protein intake postpartum (3.4 and $3.0 \mathrm{~kg} / \mathrm{d}$ for NEU and NEG, respectively). Van Saun (2006) suggested that fresh cows with $\geq 3.5$ $\mathrm{mg} / \mathrm{dL}$ of albumin were less likely to have postpartum disease. Cows fed either NEG or 1.8\% Ca had albumin concentrations slightly lower than $3.5 \mathrm{mg} / \mathrm{dL}$; no differ- ences were observed among treatments in the incidence of metabolic and reproductive disease during the trial, which averaged 5\% clinical hypocalcemia, 20\% ketosis, $5 \%$ left displaced abomasum, $17.5 \%$ retained placenta, and $2.5 \%$ metritis.

Although prepartum intake was lower for NEG and $1.8 \% \mathrm{Ca}$, the lack of difference in nonesterified fatty acid and BHB indicate that short-term energy balance was not altered among treatments. This would be expected in the absence of any metabolic challenge that typically occurs at or immediately after calving unless DMI declined significantly to cause an extended negative energy balance that was not apparent based on BHB. Compared with prepartum concentrations, all values were higher postpartum, which would be expected (Stojević et al., 2005). Changes in BW and BCS were similar among treatments, which also suggests similar energy balance among treatments.

Milk yield was $2.6 \mathrm{~kg} / \mathrm{d}$ higher from 45 through 63 DIM for cows fed NEG compared with NEU prepartum. These results are consistent with the observations of DeGroot et al. (2010) and Leno et al. (2017). However, they reported increases earlier in lactation than we observed in our current trial. The majority of the cows in our trial calved during summer and early fall, which is characterized by heat stress, which may have contributed to the delay in milk yield response. Cows were blocked by expected calving time, so any effect of heat stress is confounded with blocking. No differences were observed in milk component yield or percentage, which is consistent with prior research from Moore et 
al. (2000) and Ramos-Nieves et al. (2009). The reason for the interaction observed for MUN is not apparent and has not been reported in previous trials.

\section{CONCLUSIONS}

Results of this trial indicate that feeding an acidogenic diet (NEG), as defined by maintaining a urine $\mathrm{pH}$ of 5.5 to 6.0 , altered plasma and urine mineral concentrations to successfully improve plasma Ca concentrations by 3 DIM and increased milk yield from 45 through 63 DIM compared with NEU. Feeding $1.8 \%$ Ca prepartum improved plasma Ca at 1 DIM only compared with $1.3 \%$ Ca but did not affect milk yield. Both NEG and 1.8\% Ca decreased prepartum DMI; however, no differences were observed in postpartum DMI among treatments.

\section{REFERENCES}

AOAC International. 2000. Official Methods of Analysis. 17th ed. AOAC International, Arlington, VA.

Beede, D. K., T. E. Pilbeam, S. M. Puffenbarger, and R. J. Tempelman. 2001. Peripartum responses of Holstein cows and heifers fed graded concentrations of calcium (calcium carbonage) and anion (chloride) 3 weeks before calving. J. Dairy Sci. 88(Suppl. 1):83. (Abstr.)

Beede, D. K., and J. K. Shearer. 1991. Nutritional management of dairy cattle during hot weather. Agric. Prac. 12:5-12.

Beede, D. K., C. Wang, G. A. Donovan, L. F. Archbald, and W. K. Sanchez. 1991. Dietary cation-anion difference (electrolyte balance) in late pregnancy. Pages 1- 6 in Proc. Florida Dairy Production Conf. University of Florida, Gainesville.

Block, E. 1984. Manipulating dietary anions and cations for prepartum dairy cows to reduce incidence of milk fever. J. Dairy Sci. 67:2939-2948.

Chan, P. S., J. W. West, and J. K. Bernard. 2006. Effect of prepartum dietary calcium on intake and serum and urinary mineral concentrations of cows. J. Dairy Sci. 89:704-713.

Charbonneau, E., D. Pellerin, and G. R. Oetzel. 2006. Impact of lowering dietary cation-anion difference in nonlactating dairy cows: A meta-analysis. J. Dairy Sci. 89:537-548.

Curtis, C. R., H. N. Erb, C. J. Sniffen, R. D. Smith, and D. S. Kronfeld. 1985. Path analysis of dry period nutrition, postpartum metabolic and reproductive disorders, and mastitis in Holstein cows. J. Dairy Sci. 68:2347-2360.

DeGroot, M. A., E. Block, and P. D. French. 2010. Effect of prepartum anionic supplementation on periparturient feed intake, health, and milk production. J. Dairy Sci. 93:5268-5279.

Goff, J. P. 2008. The monitoring, prevention, and treatment of milk fever and subclinical hypocalcemia in dairy cows. Vet. J. 176:50-57.

Jacobson, D. R., R. W. Hemken, F. S. Button, and R. H. Hatton. 1972. Mineral nutrition, calcium, phosphorus, magnesium, and potassium interrelationships. J. Dairy Sci. 55:935-944.

Jardon, P. W. 1995. Using urine $\mathrm{pH}$ to monitor anionic salt programs. Compend. Contin. Educ. Pract. Vet. 17:860-866.

Leno, B. M., C. M. Ryan, T. Stokol, D. Kirk, K. P. Zanzalari, J. D. Chapman, and T. R. Overton. 2017. Effects of prepartum dietary cation-anion difference on aspects of peripartum mineral and energy metabolism and performance of multiparous Holstein cows. J. Dairy Sci. 100:1-19.
Littell, R. C., P. R. Henry, and C. A. Ammerman. 1998. Statistical analysis of repeated measured data using SAS procedures. J. Anim. Sci. 76:1216-1231.

Miller, W. J. 1983. Using mineral requirement standards in cattle feeding programs and feed formulations. Pages 69-74 in Georgia Nutrition Conference for the Feed Industry. University of Georgia, Athens.

Moore, S. J., M. J. VandeHaar, B. K. Sharma, T. E. Pilbeam, D. K. Beede, H. F. Busholtz, J. S. Liesman, R. L. Horst, and J. P. Goff. 2000. Effects of altering dietary cation-anion difference on calcium and energy metabolism in peripartum cows. J. Dairy Sci. 83:2095-2104.

NRC. 2001. Nutrient Requirements of Dairy Cattle. 7th rev. ed. National Academy of Science, Washington DC.

Oba, M., A. E. Oakley, and G. F. Tramblay. 2011. Dietary Ca concentration to minimize the risk of hypocalcemia in dairy cows is affected by the dietary cation-anion difference. Anim. Feed Sci. Technol. 164:147-153.

Oetzel, G. R. 1991. Meta-analysis of nutritional risk factors for milk fever in dairy cattle. J. Dairy Sci. 74:3900-3912.

Oetzel, G. R. 1993. Use of anionic salts for prevention of milk fever in dairy cattle. J. Dairy Sci. 76:1617-1623.

Oetzel, G. R., J. D. Olson, C. R. Curtis, and M. J. Fettman. 1988. Ammonium chloride and ammonium sulfate for prevention of parturient paresis in dairy cows. J. Dairy Sci. 71:3302-3309.

Ramos-Nieves, J. M., B. J. Thering, M. R. Waldron, P. W. Jardon, and T. R. Overton. 2009. Effects of anion supplementation to low potassium prepartum diets on macromineral status and performance of periparturient dairy cows. J. Dairy Sci. 92:5677-5691.

Shire, J. A., and D. K. Beede. 2013. DCAD revisited: Prepartum use to optimize health and lactational performance. Pages 1-11 in Proc. Southwest Nutrition and Management Conf. University of Arizona, Tucson.

Stojević, Z., J. Piršljin, S. Milinković-Tur, M. Zdelar-Tur, and B. B. Ljubić. 2005. Activities of AST, ALT and GGT in clinically healthy dairy cows during lactation and in the dry period. Vet. Arh. 75:67-73.

Vagnoni, D. B., and G. R. Oetzel. 1998. Effects of dietary-cation anion difference on the acid-base status of dry cows. J. Dairy Sci. 81:1643-1652.

van Mosel, M., A. T. Van't Klooster, F. van Mosel, and J. V. D. Kuilen. 1993. Effects of reducing dietary $[(\mathrm{Na}++\mathrm{K}+)-(\mathrm{Cl}-+\mathrm{SO} 4)]$ on the rate of calcium mobilization by dairy cows at parturition. Res. Vet. Sci. 54:1-9.

Van Saun, R. J. 2006. Metabolic profiles for evaluation of the transition period. Proc. Am. Assoc. Bov. Pract. 39:130-138.

Van Soest, P. J., J. B. Robertson, and B. A. Lewis. 1991. Methods for dietary fiber, neutral detergent fiber, and nonstarch polysaccharides in relation to animal nutrition. J. Dairy Sci. 74:3583-3597.

Vander, A. J. 1991. Renal Physiology. 4th ed. McGraw-Hill, New York, NY.

Venjakob, P. L., S. Borchardt, and W. Heuwieser. 2017. Hypocalcemia-Cow-level prevalence and preventive strategies in German dairy herds. J. Dairy Sci. 100:9258-9266.

Wildman, C. D., J. W. West, and J. K. Bernard. 2007a. Effects of dietary cation-anion difference and potassium to sodium ratio on lactating dairy cows in hot weather. J. Dairy Sci. 90:970-977.

Wildman, C. D., J. W. West, and J. K. Bernard. 2007b. Effects of dietary cation-anion difference and dietary crude protein on milk yield, acid-base biochemistry, and rumen fermentation. J. Dairy Sci. 90:4693-4700.

Wildman, E. E., G. M. Jones, P E. Wagner, R. L. Boman, H. F. Troutt Jr., and T. N. Lesh. 1982. A dairy cow body condition scoring system and its relationship to selected production characteristics. J. Dairy Sci. 65:495-501. 